\title{
Analisis Kesulitan Siswa SMP Kelas VIII pada Materi Segiempat dan Segitiga Berdasarkan Tahapan Berpikir Van Hiele
}

\author{
Linda $^{1 *}$, Martin Bernard ${ }^{2}$, Nelly Fitriani ${ }^{3}$ \\ 1,2,3 IKIP Siliwangi \\ *nda112996@gmail.com
}

Diterima: Januari 2020. Disetujui: Juni 2020. Dipublikasikan: Juli 2020.

\begin{abstract}
ABSTRAK
Penelitian ini bertujuan untuk mengetahui serta menganalisis kesulitan matematis siswadalam menyelesaikan soal matematika terutama pada materi segitiga dan segiempat. Subjek penelitian ini yaitu siswa kelas VIII SMP di Bandung. Instrumen yang digunakan yaitu tes tulis berupa esai yang berjumlah 5 soal. Penelitian ini menerapkanmetode analisis deskriptif, agar dapat mengetahui kesalahan dan kekeliruan siswa dalam menyelesaikan soal.Pengolahan data dihitung kedalam bentuk rata-rata skor siswa yang diperoleh dengan analisis berdasarkan tahapan Van Hiele. Hasil penelitian inimenyatakan bahwa ketercapaian siswa dalam memecahkan soal materi segiempat dan segitiga berdasarkan tahapan berpikir Van Hiele terbanyakberada pada tahap 1 (analisis) sebesar 87,87\%. Ketercapaian berpikir pada tahapan Van Hiele yang baik baru mencapai tahapan visualisasi (tahap 0) sebesar 12,12\%. Pada tahap 2(deduksi informal) dan tahap 3 (deduksi) siswa belum mampu mencapai tahapan tersebut. Dengan demikian dapat dilihat bahwa tingkat pemahaman siswa terhadap materi segiempat dan segitiga masih tergolong rendah sehingga terdapat kesulitan dan kendala bagi siswa dalam mengerjakan soal pada materi segiempat dan segitiga berdasarkan tahapan Van Hiele.
\end{abstract}

Kata kunci:kesulitan siswa, segiempat dan segitiga, tahap berpikir Van Hiele.

\begin{abstract}
The purpose of this research is to analyze student's mathematical difficulties in solving mathematics problems, especially in quadrilateral and triangular material. The subject of this study were students of class VIII of Junior high school in Bandung. Theinstrument used were written tests in the form of essays consists of 5 questions. This research method uses descriptive analysis of students mistakes in solving problems. The data is analysis based on Van Hiele theory.The results of this study stated that the students' achievement in solving rectangular and triangle material problems based on Van Hiele's thinking stage was mostly in stage 1 (analysis) of $87.87 \%$. The achievement of Van Hiele's good thinking stages has only reached the visualization stage (stage 0) of 12.12\%. For stage 2 (informal deduction) and stage 3 (deduction) no student has been able to reach that stage. Thus it can be seen that the level of student understanding of rectangular and triangular material is still relatively low so that there is difficulty in solving students' problems on rectangular and triangular material based on Van Hiele's thinking stages.
\end{abstract}

Keywords: Student difficulties, quadrilateral and triangular, Van Hiele Thinking stage.

How to Cite:Linda., Bernard, M., \& Fitriani, N. (2020). Analisis Kesulitan Siswa SMP Kelas VIII pada Materi Segiempat dan Segitiga Berdasarkan Tahapan Berpikir Van Hiele. Journal of Medives: Journal of Mathematics Education IKIP Veteran Semarang, 4(2), 233-242. 


\section{PENDAHULUAN}

Matematika tidak akan pernah terlepas dari kehidupan manusia. Pentingnya penggunaan ilmu matematika pada kehidupan sehari-hari membuat matematika menjadi sebuah ilmu yang wajib dipelajari oleh setiap orang. Mempelajari ilmu pada bidang matematika dapat menjadi sarana untuk mengembangkan pola pikir (mindset) dan menyelesaikan masalah. Matematika digunakan pada aktivitas manusia, misalnya kegiatan jual beli, analisis statistik, perhitungan maupun pengukuran pada suatu objek. Untuk itu, matematika penting bagikebutuhan sehari-hari sertaperlu diajarkan dan belajar di sekolah karena selalu digunakan dalam berbagai aktivitas kehidupan yang memerlukan kreativitas matematika yang sesuai.

Matematika adalah suatu materi pembelajaran yang memiliki peran penting pada bidang pendidikan. Pendidikan perlu diterapkan dan direalisasikan sejak dini, menurut Chotimah, Bernard,\& Wulandari, (2018) bahwa "Education isvery important to prepare qualified human resources and to complete in the development of science"dimana pendidikan memiliki peranan yang begitu penting untuk mempersiapkan sumber daya yang berkualitas untuk bersaing dalam pembangunan sains. Selain itu matematika sangat diperlukan dan digunakan bagi kehidupan dan kelangsungan hidup. Hamzah (2014:57) menyatakan bahwa pendidikan matematika adalah suatu upaya dalam meningkatkan dan mengembangkan daya menalar siswa, menumbuh- kembangkan kecerdasan siswa, dan mengubah perilaku menjadi lebih baik, bahkan bisa menciptakan suatu karya dari konsep matematika. Menurut Linda., Sari, Fitriani, et.al (2019) menyatakan bahwa secara tidak langsung konsep matematika dapat menciptakan suatu karya yang dapat dimanfaatkan dalam kebutuhan seharihari, hal ini tentu berkaitan dengan sikap kreatif yang dimunculkan siswa, sehingga siswa bisa menciptakan suatu karya nyata.Sekolah sebagai tempat pendidikan yang formal hendaknya mampu melaksanakan kegiatan pembelajaran matematika yang menyenangkan, berarti dan menarik sehingga pelajaran matematika yang terkesan sulit dan abstrak itu dapat dimengerti serta dipahami oleh siswa. Purwasih (2015) mengemukakan bahwa kebutuhan matematika pada zaman sekarang ialah memahami pembelajaran matematika sehingga bisa diterapkan untuk mencari solusi dari masalah matematika dan ilmu lainnya. Salah satunya yaitu pembelajaran matematika pada materi bangun datar segitiga dan segiempat.Dengan mempelajari segiempat dan segitiga tersebut, siswa dapat lebih mudah dan cekat menyelesaikan permasalahaan di kehidupan sehari-hari yang ada kaitannya dengan konsep tersebut, seperti menghitung dan mengukurluas dan keliling pada tanah.

Pembelajaran segiempat dan segitiga juga sangat penting untuk dipelajari dan harus dikuasai betul oleh siswa SMP kelas VII, karena menjadi materi prasyarat saat siswa duduk di bangku kelas VIII berikutnya dalam 
mempelajari bangun ruang pada sisi datar. Menurut Fitriani \& Nurfauziah (2019) mengemukakan bahwa "In mastering Geometry, throught which students are directed to identify forms by observing similarities, classifying them based on the characteristics of object, discovering the nature of a concept, and constructing concepts from each forms" dimanadalam penguasaan Geometri, siswa dibimbing dan diarahkan untuk mengidentifikasi bentuk dengan meng-amati kesamaan, mengklasifikasi berda-sarkan karakteristik objek, menemukan sifat suatu konsep, dan membangun konsep dari setiap bentuk.

Namun materi tersebut ialah salah satu pelajaran yang dianggap sukar bagi siswa SMP, dimana siswa sering keliru dalam mengidentifikasi bentuk segiempat dan segitiga, bahkan siswa tidak faham mengenaihubungan antara bangun segiempat.Penelitian ini pun telah dilaksanakan oleh para peneliti sebelumnya terkait dengan topik ini dan terdapat kesulitan dan kendala siswa untukmengerjakan soal-soal segiempat dan segitiga, penelitian ini dilakukan oleh Dewi (2017) mengungkapkan bahwa siswa merasa kesulitan dalam membedakan macam-macam segitiga dan segiempat, bahkan masih keliru untuk merancang strategi danmenyelesaikan soal cerita. Kesulitan pada bagian segitiga dan segiempatini bisa terjadi karena adanya pokok bahasan yang saling berkaitan dan berhubungan. Sesuai dengan hasil penelitian yang telah dilaksanakan oleh Kusniati (Sholihah \& Afriansyah, 2017)menunjukkan bahwa pencapaian pada tingkat perkembangan berpikir geometri berdasarkan teori Van Hiele dari 38 anak diperoleh 28 anak berada di tingkat 0 (visualisasi), 9 anak berada di tingkat 1 (analisis), dan 1 anak berada di tingkat deduksi informal, kesalahan dan kekeliruan banyak terjadi pada kesalahan konsep terutama pada pemahaman konsep segiempat. Untuk mengkaji lebih dalam, penulis meneliti kembali dan menganalisa kesulitan siswa mengerjakan soal materi segiempat dan segitiga dengan strategi yang tepat, salah satunya ialahpendekatan berdasarkan tahapan Van Hiele. Van Hiele memberi kesimpulan bahwa terdapat lima tahap pemahaman geometri yaitu visualisasi, analisis, pengurutan, deduksi, dan keakuratan atau rigor (Russefendi, 2005:161-163).

Pada tahapan visualisasi, siswa mampu mengenal dan mengidentifikasi bentuk-bentuk segiempat dan segitiga, namun ia belum bisa memahami sifatsifatnya secara rinci. Pada tahap analisis, siswa bisa memahami sifatsifat atau bentuk dari segiempat dan segitiga, seperti siswa dapat mengenal dan mengetahui bahwa sisi persegi panjang yang berhadapan itu sama panjang, namun ia belum faham pada bentuk geometri misalnya bujur sangkat ialah persegi panjang, jajar genjang, belah ketupat, trapesium dan segiempat. Tahap selanjutnya adalah tahap pengurutan, pada tahap pengurutan siswa dapatmengidentifikasi namanama bangun datar sesuai bentukbentuk segiempat dan segitiga serta memahami sifat-sifatnya, dan jenis-jenis segiempat, namun berpikir secara 
deduktifnya belum terlihat berkembang. Pada tahap deduksi maka berpikir deduktifnya mulai muncul dan tumbuh, tetapi masih belum berkembang secara baik. Pada tahap ini siswa memahami dan mengerti pentingnya akan unsurunsur yang tidak didefinisikan, bahkan bisa menganalisa dengan cermat. Dan pada tahap akhir, ialah tahap keakuratan (rigor), siswa bernalar formal secara sistematis dan dapat mengkonstruksisebuah pernyata-an dari manipulasi definisi, teorema dan aksioma.

Materi segiempat merupakan materi esensial dalam mata pelajaran matematika. Untuk mampu menentukan dan menemukan luas gabungan darisegiempat dan menyelesaikan soal cerita/uraianberkaitan dengan pengertian, jenis-jenis dansifat-sifat bangun datar, serta memecahkanmasalah menggunakan konsep luas dan keliling bangun datar, maka siswa sangat perlu dan harus memiliki ide atau gagasannya dalam menyelesaikan masalahnya dengan baik(Bernard, 2015). Pada dasarnya, segiempat dan segitiga ialahpembelajaran matematika yang harus dipelajari dan dikuasai oleh siswa sebagai prasyarat. Hal ini dikarenakan materi geometri telahdikenal serta diketahui oleh siswa sebelum masuk sekolah, misalnya titik, garis dan bidang namun belum secara sistematis. "The triangle is part of geometry concept and very important in helpstudents to solve problems encounterin daily life. This can be done by modeling the problem into a mathematical model" artinya segitiga adalah bagian dari konsep geometri, danbegitu penting dalam membantu siswa untuk menyelesaikankonflik/masalah yang dihadapinyadikehidupan sehari-hari. Hal ini dapat direalisasikan dengan memodelkan masalah menjadi model matematika (Ningsih, Nurlaelah, \& Jupri, 2018).

Untuk memperoleh prestasi dan keberhasilan dalam matematika tidaklah mudah, sangat dibutuhkan potensi individu yang memiliki daya juang yang tinggi, rasa penasaran dan ingin tahu serta berjiwa semangat dalam menekuni proses belajar matematika. Namun, pada umumnya strategi berpikir siswa SMP pada materi segiempat masih rendah,sejalan dengan Cahyani dan Fitrianna (2017)menyatakan bahwa guru merasa gagal dalam mengjaar ialah ketika penyampaian dan pengkajian materi yang dijelaskan tidak sampai kepada pemahaman siswa, tidak membangkit-kan perhatian dan keaktifansiswa dalam mengikuti pelajaranmatematika. Sehingga, minat belajar, resiliensi, dan motivasi siswa untuk belajar matematika itu rendah serta menyebabkan siswa menjadi malas, bahkan takut dan tidak tertarik untuk belajar matematika.Untuk lebih menganalisa, maka penulis mengajukan sebuah studi dengan judul "Analisis Kesulitan Siswa SMP Kelas VIII pada Materi Segiempat dan Segitiga Berdasarkan Tahapan Berpikir Van Hiele".

\section{METODEPENELITIAN}

Penelitian ini menggunakan metode jeniskualitatif deskriptif, dimana penelitian ini akan diketahui gaya kognitif siswa kemudian dideskripsikan 
bagaimana tahapan berpikir geometri siswa tersebut berdasarkan teori Van Hiele sertabertujuan untuk menggambarkan dan menganalisis kesulitan dan kendala siswa dalam memecahkan soal matematika terutama materi segitiga dan segiempat. Populasi penelitian ini yakni seluruh siswa SMP, untuk sampel dipilih secara purposive samplingialah satu kelas pada satu sekolah di wilayah Kota Bandung, Jawa Barat.Padates penelitian ini berdasarkan teori Van Hieleyang dimaksudkan untuk mengetahui pencapaian siswa terhadap tahapan berpikir yang dimilikinya berdasarkan tahap Van Hiele.

Instrumen yang digunakan berupa tes tertulis dalam bentukesaiberjumlah 5 butir soal yang sudah teruji validitas, reliabilitas, indeks kesukaran dandaya pembeda, angket danwawancara. Adapun indikator soal yang digunakan yaitu: 1) menggambarkan sketsa segitiga siku-siku yang dideskripsikan dan menemukan keliling segitiga sikusiku sesuai dari ukuran yang ditentukan, 2) menentukan keliling segitiga mengguna-kan ukuran bentuk aljabar sehingga adanya pengembangan keterkaitan antar materi segitiga denganmateri persamaan satu variabel, 3) menjelaskanlangkah-langkah penyelesaian suatu masalah dalam menentukan luas segitigalalu membandingkan luas segitiga dari ukuran yang berbeda, 4) menggambarkan sketsa persegi panjangdariilustrasi dan menentukan luas persegi panjang, dan 5)menghitungdan mengukur panjang sisi sejajar dan tinggi yang pada trapesium.
Prosedur penelitian terdiri dari 3 tahap, yaitu: 1) tahap persiapan, 2) tahap pelaksanaan, dan 3) tahap evaluasi. Langkah-langkah tahap persiapan yang dilakukan, ialah: (1) melakukan perizin-an kepada sekolah dan memilih siswa SMPN 41 Bandungsebagai sampel penelitian; (2) menyiapkan instrumen tes dan non-tes; (3) memperbaiki instrumen penelitian berdasarkan hasil validasi. Pada tahap pelaksanaan yaitu: (1) memberikan tes soal kepada siswa kelas VIII SMPN 41 Bandung, dan (2) menghitung dan menganalisis jawaban dari hasil penelitian. Tahap akhir (evaluasi) meliputi: 1)mengolah dan menganalisadata yang didapat dari hasil tes, 2)menggambarkan dan mendeskripsikan hasil analisis data kemudianmembuat kesimpulan sebagai respon dari rumusan masalah, dan 3)menyusun laporan penelitian. Kemampuan mate-matis siswa tentuberbeda-beda, untuk membedakannya menggunakan acuan atau patokan, peneliti mengelompokkan siswa ke dalam 3 kelompok berpikir. Kelompok tersebut terdiri dari kelompok rendah, sedang dan tinggi.

\section{HASIL DAN PEMBAHASAN}

Pada penelitian yang dilaksanakan dikelas VIII-2 SMPN 41 Bandung pada tanggal 19 November 2019 tentang segiempat dan segitiga. Kami menguji 33 orang siswa dari 1 kelas yang kami ambil kelas VIII-2. Instrumen yang diterapkan ialah instrumen bentuk lembar tes soal uraian, angket dan wawancara. Instrumen lembar tes soal digunakan untuk menelaah dan 
mengetahui apakah siswa mampu dalam memecahkan soal-soal padasegitiga dan segiempat. Tes soal terdiri dari 5 butir soal esaidimana masing-masing soal memiliki tahapan berdasarkan Van Hielelalu diberikan kepada siswa, pada saat pemberian soal peneliti tidak mengalami kendala dan penelitian dapat dilaksanakan dengan baik. Setelah tes dilaksanakan, maka akan dilakukan analisis hasil siswa tiap soal dengan skor rata-rata. Adapun skor rata-rata yang didapat oleh siswa tercantum pada Gambar 1.

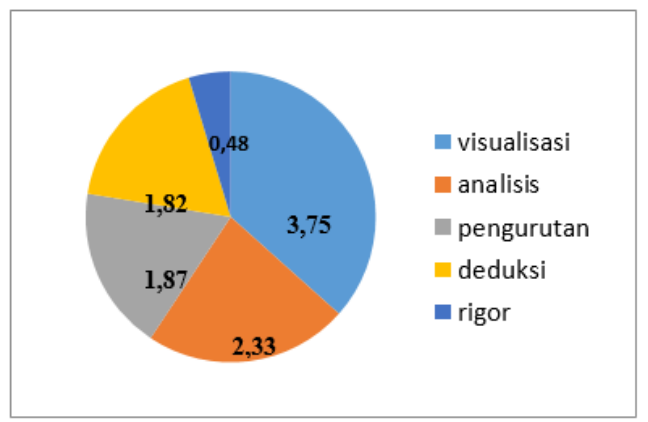

Gambar 1. Diagram Rata-Rata Skor Siswa dalam Menyelesaikan Soal Materi Segiempat dan Segitiga

Dari Gambar 1 diperoleh rata-rata skor siswa pada tiap butir soal. Pada soal nomor 1 dengan tahap visualisasi nilai rata-rata siswa mencapai 3,75 ,soal nomor 2 tahap analisis rata-rata skor siswa sebesar 2,33, soal nomor 3 tahap pengurutan sebesar 1,87 , soal nomor 4 tahap deduksi sebesar 1,82 dan di soal nomor 5 tahap rigor sebesar 0,48. Dari data tersebut dapat dinyatakan bahwa semakin tinggi tingkatan pada tahap Van Hiele maka semakin rendah skor rata-rata yang didapat siswa, hal ini berarti ketika pada tahap analisis skor siswa rendah maka pada tahap-tahap berikutnya pun akan semakin rendah karena terdapat kesulitan atau kendala pada siswa untukmenyelesaikan soal. Lembar tes berupa soal cerita, soal tersebut di susun berdasarkan standar kompetensi.

Pada jawaban nomor 1 tahap visualisasi, pada tahap inisiswa dapat mengkonstruksikan masalah atau konteksmatematikapada sebuah gambar, namun di tahap analisis siswa masih keliru dalam menuliskan kalimat matematika dengan baik, walaupun hasilnya benar namun langkah pengerjaannya kurang memenuhi konsep baik dalam menentukan rumus maupun tata penulisan kalimat matematika.
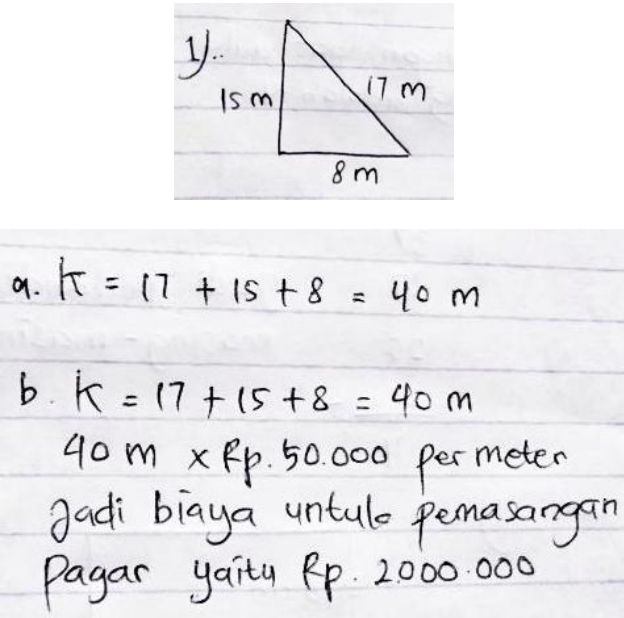

Gambar 2. Jawaban Soal 1

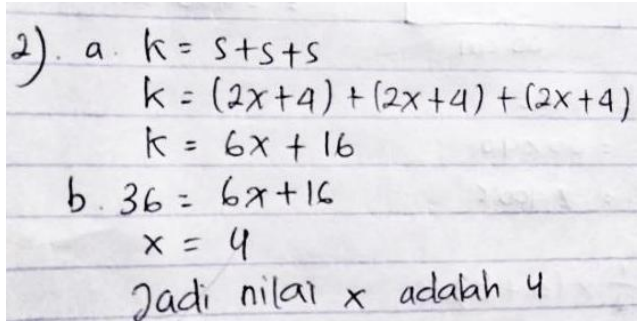

Gambar 3. Jawaban Soal 2

Pada soal nomor 2, diperoleh jawaban siswa berdasarkan tahap 
analisis pada tahapan Van Hiele, adalah sebagai berikut.

1. Siswa keliru dalam menentukan operasi penjumlahan dari bentuk aljabar yang bertujuan untuk menghitung keliling segitiga.

2. Siswa keliru dalam menentukan hasil operasi bilangan pada penjumlahan dan perkalian.

3. Siswa tidakfaham mengenai operasi bilangan dengan bentuk linear satu variabel, sehingga sulit untuk menentukan nilai $x$ yang merupakan konten yang dipertanyakan pada soal.

Untuk soal nomor 3, diperoleh jawaban siswa di tahap pengurutan sebagai berikut.

1. Siswa keliru dalam menerapkan persamaandalam menentukan luas segitiga.

2. Siswabelum membandingkan hasil dari luas segitiga yang sesuai dengan urutan luasmasing-masing segitiga yang diperoleh.

3. Siswa tidak mampu menentukan bagaimana cara membandingkan suatu luas segitiga serta mengurutkan perbandingan sesuai yang ditentukan.

4. Siswa kurangmengetahui arti dari perbandingan, sehingga pebandingan tersebut dimaknai sama dengan pengurangan.

5. Siswa belum bisamenerapkan rumus yang tepat.

6. Siswa belum dapat memaknai dan mengkonstruksi gambar dengan tepat.

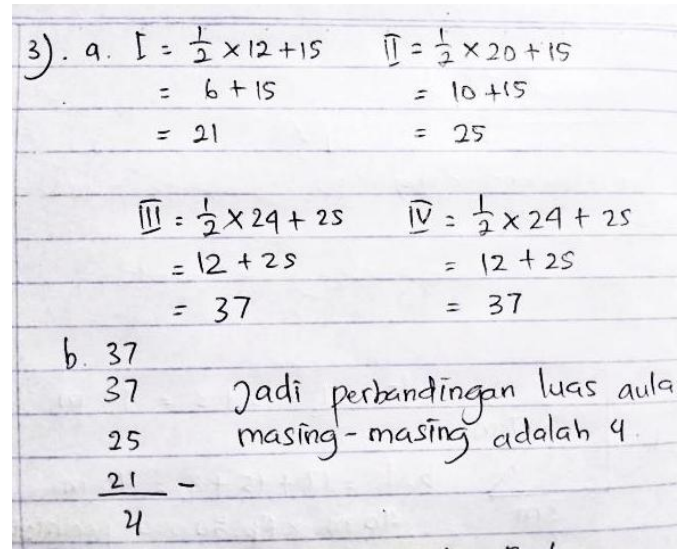

Gambar 4. Jawaban Soal 3

Pada soal nomor 4 diperoleh jawaban siswa berdasarkan tahap deduksi sebagai berikut.

1. Siswa sudah mampu dalam mengkonstruksi dari soal cerita ke dalam bentuk gambar nyata.

2. Siswa masih keliru dalam menentukan satuan luas persegi panjang.

3. Siswa tidak membuat kesimpulan yang bersifat deduktif, sehingga siswa hanya mengklarifikasi dengan menerapkan rumus luas segiempat tanpa adanya pernyataan yang memunculkan kesimpulan bahwa darimana konsep yang ditemukan siswa untukmemecahkan soal tersebut.

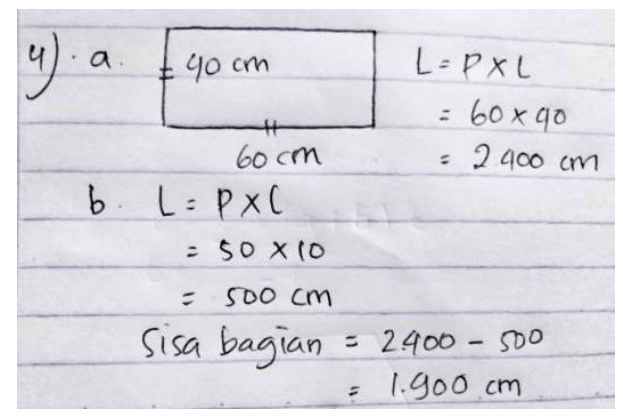

Gambar 5. Jawaban Soal 4

Berdasarkan hasil penyelesaian soal nomor 5 tahap rigor, diperoleh sebagai berikut. 
1. Siswa tidak mengerti mengenai kalimat pernyataan dari soal.

2. Siswa tidak mampu menemukan ukuran tinggi dan sisi sejajar pada trapesium melalui suatu pembuktian pada luas trapesium saling berkaitan, sehingga siswa tidak menambahkan atau memperjelas gagasan dari penyelesaian tersebut.

3. Siswa tidak menerapkan rumus luas trapesium dengan baik.

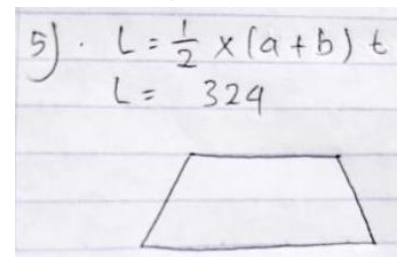

Gambar 6. Jawaban Soal 5

Berdasarkan hasil tes diperoleh kesulitan dan kendala siswa dalam menentukan jawaban padasoalsegitiga dan segiempat yaitu 4 siswa pada tahap 0 (tahap visualisasi) dan 29 siswa pada tahap 1 (tahap analisis). Dengan demikian, dapat dinyatakan bahwa siswa yang gagal mencapai tingkat sebelum-nya, maka kemungkinan pula sulit untuk mencapai tingkat selanjutnya. Hal ini sejalan dengan Van Hiele yang menyatakan bahwa siswabelajarmateri geometri melalui tingkat-tingkat tersebut dengan tahapan yang sama dan tidak adan tingkatan yang diloncati dan dilalui egitu saja, serta harus bertahap (Kusniati:106). Berdasarkan penelitian yang dilakukan, diperoleh ketercapaian skor siswa pada tiap soal berdasarkan tahapan Van Hiele yang dapat dilihat pada Tabel 1 .

Tabel 1. Ketercapaian Kompetensi Siswa Berdasarkan Tahap Berpikir Van Hiele

Kelom No Pencapaian Persentase

\begin{tabular}{cccc}
\hline -pok & $\begin{array}{c}\text { Butir } \\
\text { Soal }\end{array}$ & $\begin{array}{c}\text { Tahapan } \\
\text { Van Hiele }\end{array}$ & $\begin{array}{c}\text { Pencapaian } \\
\text { Tahapan } \\
\text { Van Hiele }\end{array}$ \\
\hline \multirow{2}{*}{ Tinggi } & 1 & Visualisasi & $12,12 \%$ \\
\cline { 2 - 4 } Sedang & 1 & Analisis & \\
& 2 & Analisis & \\
\multirow{2}{*}{ Rendah } & 3 & Analisis & $87,87 \%$ \\
& 4 & Analisis & \\
& 5 & Analisis & \\
\hline
\end{tabular}

Menurut Tabel1 didapatkan bahwa ketercapaian siswa untuk menyelesaikan masalah berdasarkan tahapan Van Hiele terbanyak berada pada tahapan 1 (analisis). Ketercapaian tahapan Van Hiele yang baik baru mencapai tahapan visualisasi (tahap 0). Sedangkan tahap 2(deduksi informal) dan tahap 3 (deduksi) siswabelum mencapai tahapan tersebut dengan baik. Selain itu, ketercapaian berpikir antara kelompok rendah dan sedang menunjukkan hasil yang sama. Siswa pada kelompok rendah dan sedang masih kesulitan dalam menganalisis sifat-sifat dari segiempat dan segitiga, terutama pada rumus luas dan keliling. Dalam menyusun strategi untuk mengerjakansoal matematika pada segiempat dan segitiga, siswa merasa kesulitan dalam menganalisisdari masalah segitiga dan segiempat yang diberikan dan menyebabkan siswa belum berhasil dalam mencapai tahapan lebih tinggi pada tahapan Van Hiele.

\section{PENUTUP}

Dari penelitian yang telah dilakukan di kelas VIII pada materi segiempat dan segitigadiperoleh skor siswa dalam memecahkan soal yang telah disajikan berdasarkan tahapan Van Hiele. Pada tahapanVan Hiele 
terbanyak berada pada tahap 1 (analisis) sebesar $87,87 \%$. Ketercapaian tahapan Van Hiele yang baik baru mencapai tahapan visualisasi (tahap 0) sebesar $12,12 \%$. Sedangkan tahap 2(deduksi informal) dan tahap 3 (deduksi) siswa belum bisa mencapai tahapan tersebut. Ada beberapa hal yang menjadi penyebab siswa merasa kesulitan dalam memecah-kan soal segitiga dan segiempat antara lain: 1) siswa keliru untuk menghitung operasi penjumlahan dari bentuk aljabar untuk menentukan dan menghitung keliling segitiga, 2) siswa keliru dalam menentukan luassegitiga sertatidak mampu dalam membandingkan hasil dari luas segitiga dengan urutan luasdari masing-masing segitiga serta siswa belum mengetahui bagaimana cara membandingkan suatu luas segitiga, 3) siswa belum bisa membuat kesimpulan yang bersifat deduktif, sehingga siswa hanya mengklarifikasi dengan menerap-kan rumus luas segiempat tanpa adanya pernyataan yang memunculkan kesimpulan bahwadarimana konsep yang didapatkan siswa dalam menjawab soal, dan 4) siswa kurang memaknai kalimat pernyataan dari soal, siswa kurang mampu menemukan ukuran tinggi dan sisi sejajar pada trapesium melalui suatu pembuktian pada luas trapesiumsaling berkaitan, sehingga siswa tidak mampumenambahkan informasi atau cara lainserta memperinci gagasan dari penyelesaiansoal tersebut.

\section{DAFTAR PUSTAKA}

Bernard, M. (2015). Meningkatkan Kemampuan Komunikasi dan Penalaran serta Disposisi Matematik Siswa SMK dengan Pendekatan Kontekstual melalui Game Adobe Flash CS 4.0. Jurnal Ilmiah Program Studi Matematika STKIP Siliwangi Bandung, 4(2), 197-222.

Cahyani, E.P., \& Fitrianna, A.Y. (2017). Analisis Kemampuan Penalaran Matematis Siswa pada Materi Barisan dan Deret di SMKN 1 Cipanas.Prosiding Seminar Nasional Matematika dan Pendidikan Matematika STKIP Siliwangi. Bandung: Jurusan Pendidikan Matematika STKIP Siliwangi.

Chotimah, S., Bernard, M., \& Wulandari, S. M. (2018). Contextual Approach Using VBA Learning Media to Improve Students' Mathematical Displacement and Disposition Ability.Journal of Physics: Conference Series 948012025.

Dewi, S. C. (2017). Analisis Kesulitan Pemahaman Konsep Pada Materi Segitiga Dan Segiempat Di Kelas VII SMP Negeri 2 Kembang Tahun Ajar 2016/2017.SkripsiSTKIP

Siliwangi Bandung: Tidak diterbitkan.

Fitriani, N., \& Nurfauziah, P. (2019). Gender and Mathematical Abstraction on Geometry. Journal of Physics: Conference Series 1315012052.

Hamzah, A. (2014). Perencanaan dan Strategi Pembelajaran Matematika. Jakarta: Rajawali Pers. 
Linda., Sari, D. R., Fitriani, N., \& Nurfauziah, F. (2019). Penerapan Pembelajaran Berbasis Etnomatematika Berbantuan VBA for Microsoft Excel terhadap Resiliensi Siswa SMP.JPMI, 2(5), 293-300.

Ningsih, D. R., Nurlaelah, E., \& Jupri, A. (2018). Preliminary Study on Mathematical Problem Solving Ability of Junior High School Students on the Triangle Subject. JournalInternational Conference on Mathematics and Science Education, 3(2), 745-750.
Purwasih, Ratni. (2015). Peningkatan Kemampuan Pemahaman Matematis dan Self Confidence Siswa Mts di Kota Cimahi melalui Model Pembelajaran Inkuiri Terbimbing. Jurnal Ilmiah STKIP Siliwangi Bandung, 9 (1),16-25.

Ruseffendi, E. T. (2005). Pengantar Kepada Membantu Guru Mengembangkan Kompetensi Dalam Pengajaran Matematika Untuk Meningkatkan CBSA. Bandung: Tarsito.

Sholihah, S. Z., \& Afriansyah, E. A. (2017). Analisis Kesulitan Siswa dalam Proses Pemecahan Masalah Geometri Berdasarkan Tahapan Berpikir Van Hiele.Jurnal Mosharafa 6(2), 287-298. 